http://dx.doi.org/10.1007/s11356-012-1206-4

(c) 2012, Springer-Verlag Berlin

The original publication is available at http://www.springerlink.com

\title{
Organochlorinated pesticides, PCBs, dioxins, and PBDEs in grey mullets (Liza ramada) and allis shads (Alosa alosa) from the Vilaine estuary (France)
}

\author{
Gilles Bocquené, Alain Abarnou
}

Ifremer, Centre Atlantique, Unité de Biogéochimie \& Écotoxicologie, Cellule d'Analyse de Risque Chimique, Rue de l'lle d'Yeu, BP 21105, 44311, Nantes Cedex 03, France

*: Corresponding author : Gilles Bocquené, email address : gbocquen@ifremer.fr

\begin{abstract}
:
This study aimed to compare the contamination levels of various organohalogenated compounds in two migratory fish species in the Vilaine River in western France. Organochlorinated pesticides, polychlorinated biphenyls (PCBs), dioxins (polychlorinated dibenzo- $p$-dioxins/dibenzofurans (PCDDs/Fs)), and polybrominated diphenyl ethers (PBDEs) were analyzed in two diadromous species from the Vilaine estuary, the grey mullet (Liza ramada) - an amphihaline species, and the allis shad (Alosa alosa) -an anadromous species. Fish were collected in spring 2004 and spring 2005, upstream and downstream of the Arzal Dam. PCB contamination varied from 27 to $200 \mathrm{ng} \mathrm{g}^{-1}$ dry weight (d.w.). PCDDs/Fs, expressed in toxicity equivalent quantity (TEQ) varied from 0.4 to $2.8 \mathrm{pg} \mathrm{g}^{-1} \mathrm{~d}$.w. Dioxins and dioxin-like PCBs expressed in total TEQ varied from 1.4 to $18.8 \mathrm{pg} \mathrm{g}^{-1} \mathrm{~d}$.w. PBDE47 was present at around 2-10 $\mathrm{ng} \mathrm{g}^{-1}$ d.w. and concentrations of the insecticide dichlorodiphenyltrichloroethane breakdown product $p, p^{\prime}$-dichlorodiphenylchloroethylene varied from 1 to $14 \mathrm{ng} \mathrm{g}^{-1} \mathrm{~d}$.w. For both species, specimens collected upstream were more contaminated. The grey mullet specimens were less contaminated than the allis shad when taken downstream of the dam but were more contaminated upstream. The allis shads presented intermediate contaminant concentrations with a less pronounced difference between upstream and downstream specimens. However, it is thought that shads do not feed when they spawn in the upstream parts of rivers, which should modify the contaminant concentrations. However, measurements in upstream shad samples show an unexpected increase of the contamination, which remains unexplained.
\end{abstract}

Keywords: Vilaine estuary ; Organohalogenated contaminants ; PCBs ; DDT ; Dioxins ; Shad ; Grey mullet ; Bioaccumulation 


\section{Introduction}

The bioaccumulation of persistent organic pollutants (POPs) is of very great concern for both the environmental quality of aquatic ecosystems and for human health. Among POPs, legacy contaminants such as organochlorinated pesticides like dichlorodiphenyltrichloroethane (DDT) and its metabolites and hexachlorocyclohexane $(\mathrm{HCH})$ isomers or polychlorinated biphenyls (PCBs) are still commonly measured in wild fauna despite their being phasing out. However, PCBs are typical examples of such pollutants that require an improved risk assessment and appropriate measures to limit their environmental contamination and human exposure (Birnbaum and Staskal-Wikoff, 2010). The term dioxins refers to polychlorinated dibenzo-p-dioxins (PCDDs) and polychlorinated dibenzofurans (PCDFs). These compounds are unintentionally produced as unwanted contaminants emitted during chemical processes, or during the incineration of solid wastes. Dioxins and dioxin-like PCBs (DL-PCBs) are commonly associated because they present the same toxicity mechanisms due to their similar structural characteristics. For this reason, they are often measured according to the same analytical reference protocol and their concentrations are expressed in Toxicity Equivalent Quantity (TEQ) using a Toxicity Equivalent Factor (van den Berg et al.,1998; van den Berg et al., 2006) which is a factor to account for the relative toxicity compared with that of to the 2378-TCCD (tetrachlorodibenzo-p-dioxin). Polybrominated diphenyl ethers (PBDEs) are a class of more recently measured environmental contaminants; their presence in the environment results from extensive use as flame retardants in household and automobile equipment, furniture, clothes, insulating material, and electronic devices (Law et al. 2005; Yogui and Sericano, 2009). The use of these products has been restricted in many countries.

One common property of all these organohalogenated contaminants is their capacity to enter the food chain and to accumulate in the lipid-rich tissues of aquatic organisms. Once in the food cycle they can produce harmful effects to wild life and human health. For example, the consumption of contaminated fish and seafood poses a major risk to human health. For aquatic biota, dietary intake is recognized as the prevailing source of contamination and increases in importance with higher trophic level species. Thus, the contamination levels in aquatic species depend on the dietary habits of each species in relation with their habitat and their recent biological background such as feeding habits or starvation during their migration.

Diadromous fish species are species that migrate to spawn either from marine waters towards riverine freshwater like salmon, shad and other anadromous species or, oppositely, from the upper river to the sea, like eels, grey mullets and other catadromous species. During their migration period, anadromous species like shad are supposed to stop feeding (Mennesson-Boisneau, 1990; Taverny,1991) whereas grey mullet still eat during their travel from the river to the spawning areas (Almeida et al. 1993; Almeida, 2003).

This study attempted to differentiate the combined effects of migration and feeding on the contamination of two diadromous species. The study site is the estuary of the Vilaine River, a river flowing into the Atlantic Ocean in southern Brittany. Several groups of organohalogenated contaminants were analyzed in samples of the anadromous allis shad (Alosa alosa) and the catadromous grey mullet (Liza ramada) and the contamination levels were compared. 


\section{Materials and method}

\subsection{Choice of the studied species}

The allis shad (Alosa alosa) and the grey mullet (Liza ramada) were the selected species. The allis shad lives at sea and returns to the river at the end of the winter where they reproduce between the middle of spring and the early summer. According to Baglinière et al. (2003), the allis shad is predominantly semelparous, however, some specimens may spawn at least twice during their life (King and Roche, 2008). The allis shad feeds on various species but mainly on small crustaceans (mysids, decapoda, copepods) and on small pelagic fat fish like sprat and anchovy (Lochet et al. 2008). Several authors have observed that shads stop feeding when they reach freshwater for spawning (Taverny 1991; Sabatié 1993; Baglinière 2000; Mennesson-Boisneau et al. 2000a). The allis shad is now classified as a vulnerable species and has been included in appendix III of the Bern Convention (1979) and in Annex II species in the European Union's Habitat Directive (2002) that both list protected fauna species in Europe.

The grey mullet was the second species included in this study. These fish migrate from the marine zone to areas downstream sometime between the middle of spring to the end of summer. Unlike that of the allis shad, the migration of the grey mullet has no reproductive purpose but fulfills trophic needs. Its diet is mainly detrital elements of plant or animal origin, but they rely partly upon sediment as well resulting in a high percentage of particulate organic matter and large granulometric classes of sediment in their stomach (Almeida et al. 1993). Thus, the grey mullet is considered an integrative species and potentially an interesting sentinel species.

\subsection{Sampling}

The study area (Figure 1) was located in the lower part of the Vilaine River. This river $\left(218 \mathrm{~km}\right.$ long, average discharge around $80 \mathrm{~m}^{3} \mathrm{~s}^{-1}$, http://www.hydro.eaufrance.fr/) is located in Brittany, west of France, and flows into the Atlantic Ocean. Its basin area, approximately $10,900 \mathrm{~km}^{2}$, is characterized by an oceanic climate and agricultural activities. Rennes and Redon, with about 350,000 and 10,000 inhabitants, respectively, are the main cities located on the Vilaine River. Downstream, a dam was built at Arzal in 1970 to regulate the river flow and to prevent the area from floods. This dam artificially separates the freshwater from brackish waters within the estuary. 
Figure 1: Location of sampling sites in the Vilaine River

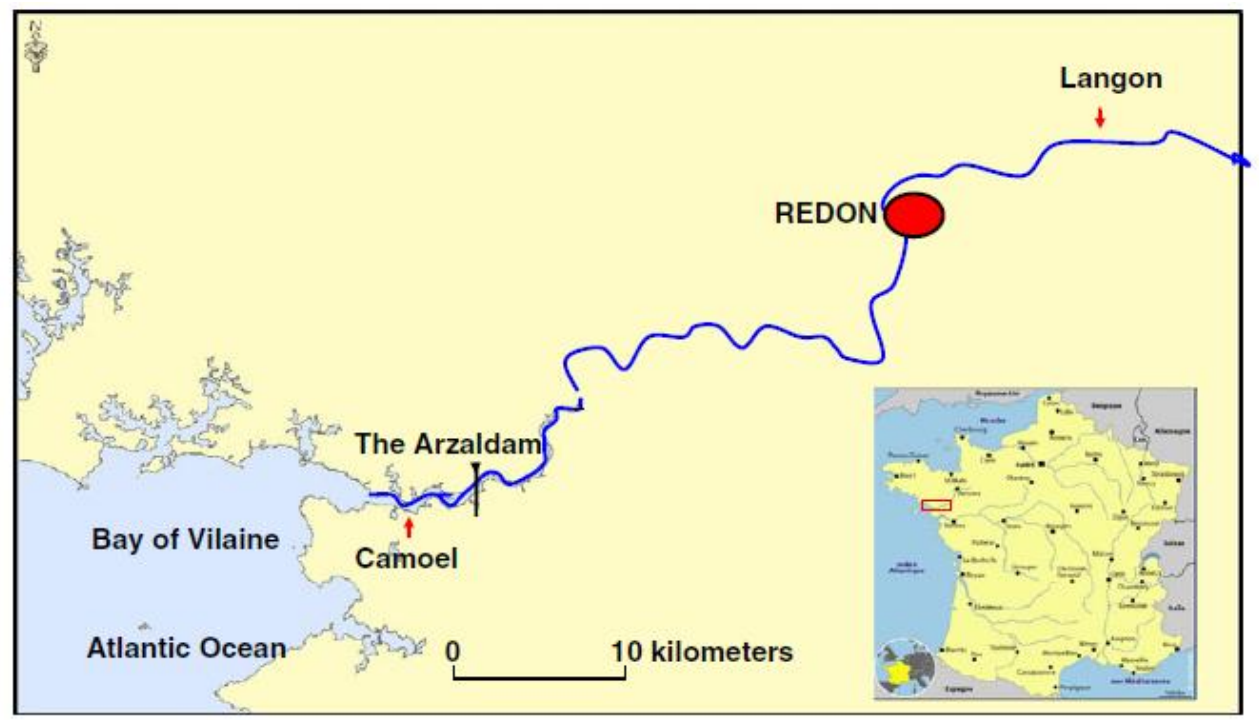

Fish were collected in spring 2004 and 2005 during migration period. The samples were taken both upstream and downstream of the Arzal dam at a fish pass which allows diadromous fish to migrate from one side to the other. Shads and grey mullets were collected by local fishermen at Langon $60 \mathrm{~km}$ upstream of the dam and at Camoel downstream in the euryhaline zone (figure 1). Each specimen was precisely identified and measured; their age was determined by scalimetry (examination of scales) by partners of this research project (Laboratory of Ecology and Quality of Continental Systems, INRA, Rennes) following Baglinière et al, 2001. the gender was determined when possible by macroscopic observation of the gonads (Table 1).

Table 1: Characteristics of the analyzed samples. $\mathrm{Nd}=$ not determined

\begin{tabular}{|c|c|c|c|c|c|c|}
\hline \multirow{2}{*}{ Species } & \multirow[b]{2}{*}{$\begin{array}{c}\text { Sampling } \\
\text { date }\end{array}$} & \multirow[b]{2}{*}{$\begin{array}{c}\text { Sampling } \\
\text { site }\end{array}$} & \multirow[b]{2}{*}{$\begin{array}{l}\text { Number of } \\
\text { specimens }\end{array}$} & \multicolumn{2}{|r|}{ Age } & \multirow{2}{*}{$\begin{array}{l}\text { Gender } \\
\text { Males / } \\
\text { females }\end{array}$} \\
\hline & & & & $\begin{array}{c}\text { Size } \pm \\
\text { SD } \\
\text { cm }\end{array}$ & (years) & \\
\hline \multirow{4}{*}{$\begin{array}{l}\text { Grey } \\
\text { mullet }\end{array}$} & \multirow{2}{*}{$\begin{array}{c}\text { Spring } \\
2004 \\
\text { Spring } \\
2004\end{array}$} & upstream & 16 & $53.7 \pm 3.4$ & $7 / 8$ & nd \\
\hline & & downstream & 8 & $\begin{array}{c}36.3 \pm \\
6.3\end{array}$ & 5 & nd \\
\hline & \multirow{2}{*}{$\begin{array}{l}\text { Spring } \\
2005 \\
\text { Spring } \\
2005\end{array}$} & upstream & 16 & $\begin{array}{c}55.2 \pm \\
1.7 \\
\end{array}$ & $7 / 8$ & nd \\
\hline & & downstream & 15 & $\begin{array}{c}55.9 \pm \\
2.9\end{array}$ & $7 / 8$ & nd \\
\hline \multirow[b]{4}{*}{ Allis shad } & \multirow{2}{*}{$\begin{array}{l}\text { Spring } \\
2004 \\
\text { Spring } \\
2004 \\
\end{array}$} & upstream & 15 & $\begin{array}{c}52.4 \pm \\
4.8 \\
\end{array}$ & 5 & $9 / 6$ \\
\hline & & downstream & 23 & $\begin{array}{c}24.8 \pm \\
3.6\end{array}$ & $2 / 3$ & nd \\
\hline & \multirow{2}{*}{$\begin{array}{l}\text { Spring } \\
2005 \\
\text { Spring } \\
2005\end{array}$} & upstream & 16 & $54 \pm 2.2$ & 5 & $6 / 10$ \\
\hline & & downstream & 15 & $\begin{array}{c}53.7 \pm \\
2.6\end{array}$ & 5 & $9 / 6$ \\
\hline
\end{tabular}


An attempt was done to obtain fish samples of comparable size and age, as these variables vary together. However, this has not been achieved as sampling is tightly dependant on availability of different fish size classes when trawling. This is particularly true in the case of fishes collected downstream of the dam in spring 2004 that were smaller and did not belong to the same year class than the other sampled fishes, 5 years instead of $7 / 8$ years in the case of the grey mullet and $2 / 3$ years instead of 5 years in the case of the allis shad.

\subsection{Analyses}

Approximately $50 \mathrm{~g}$ from the dorsal muscle from each specimen were collected. All the samples were pooled together according to the species, the sampling period and the sampling location to obtain eight groups. Analyses were performed after freeze-drying and homogenization of pools. Between 5 - $22 \mathrm{~g}$ of sample were used for dioxins and furans analyses and between $0.1-0.4 \mathrm{~g}$ were used for PCB-DL analyses. Several groups of organic contaminants were analyzed in the eight fish samples by an analytical laboratory following recommended analytical procedures for non polar pesticides and PCBs (European Committee for standardization EN 1528-2). Purification and analyses were done with respect of the norms EN 1948-2 and 1948-3. The reference protocol included a solvent extraction step, followed by an appropriate clean up and pre-separation of the extracts. The analytical laboratory is under accreditation $n^{\circ} 1-1351$ delivered by the French Committee for Accreditation, program 99-2 "Chemical contaminants in animals", program GTA 26 "Analysis of pesticides residues and organic contaminants in food and biological material". Quality assurance included the analysis of blanks, the assessment of recoveries, reproductibilities and accuracy of the data relative to certified reference material.

The compounds determined were: organochlorinated pesticides, including the three main $\mathrm{HCH}$ isomers $\alpha-, \beta$-, and $\gamma$ and the six components of DDT: $0, p^{\prime}$ and $p, p^{\prime} \mathrm{DDT}, o, p^{\prime}$ and $p, p^{\prime}$ dichlorodiphenylchloroethylene (DDE) and $o, p^{\prime}$ and $p, p^{\prime}$ dichlorodiphenyldichloroethane (DDD). PCBs were tested, including both groups of the seven International Council for the Exploration of the Sea (ICES) marker PCB congeners (PCB28, 52, 101, 118, 138, 153, 180) and of the 12 DL-PCB congeners (PCB77, 81, 105, 114, 118, 123, 126, 156, 157, 167, 169, 189). All the 2378 substituted isomers of the PCDDs, PCDFs, and PBDEs congeners (PBDE47, 77, 99, 100, 153, 181, 209) were also tested. Contaminants were then determined and quantified by high resolution gas chromatography and either by electron capture detection (ECD) for ICES-PCBs and organo-chlorinated pesticides (OCPs) or by high resolution mass spectrometry for DL-PCBs, PCDDs, PCDFs and PBDEs enabling a very low quantification threshold. Limits of quantification (LOQ) are at the $0.1-0.5 \mathrm{pg} . \mathrm{g}^{-1}$ levels depending of the compounds for most of these components and the estimated precision is better than 10\%. Concentrations of dioxins and dioxin-like compounds (PCDDs, PCDFs and DL-PCBs) were expressed in TEQ, which was calculated using two sets of Toxic Equivalency Factors (TEFs) (van den Berg et al. 1998; van den Berg et al. 2006) to allow comparisons with published results or with the maximum levels of contaminants in food set by the recent regulations.

Other compounds were searched in the muscle fish samples; they were chlorinated phenoxy acetic acid derivatives (24-D, 24-MCPA, 24-DP, MCPP and 245-T) with limits of quantification (LOQ) set at $10 \mathrm{ng} \cdot \mathrm{g}^{-1}$ and endosulfan compounds $(\alpha, \beta$ - endosulfan and endosulfan sulfate with a LOQ of 5,20 and 5 ng. $\mathrm{g}^{-1}$ respectively). 


\section{Results and discussion}

Results (Table 2) are given for the contaminants which have been quantified (conc. >LOQ).

Neither chlorophenoxy acetic acids nor compounds of the endosulfan group were found in the muscle tissue of fish from the Vilaine River. Those contaminants might result from earlier use as an herbicidal (phenoxy acid derivatives) or an insecticidal (endosulfan) which now have been restricted or even forbidden. It is possible that they have degraded, or do not easily accumulate in tissue. This could explain why they are not found in our samples. However, it is also possible that the LOQ, between 5 and $20 \mathrm{ng}^{-1}{ }^{-1}$, was not sufficiently low to obtain definitive information on their presence in fish.

Table2 : Concentrations of organohalogenated contaminants in fish muscle tissue samples.

\begin{tabular}{|c|c|c|c|c|c|c|c|c|}
\hline & \multicolumn{4}{|c|}{ Grey mullet (Liza ramada) } & \multicolumn{4}{|c|}{ Allis shad (Alosa alosa) } \\
\hline & \multicolumn{2}{|c|}{ Downstream } & \multicolumn{2}{|c|}{ Upstream } & \multicolumn{2}{|c|}{ Downstream } & \multicolumn{2}{|c|}{ Upstream } \\
\hline & 2004 & 2005 & 2004 & 2005 & 2004 & 2005 & 2004 & 2005 \\
\hline \multicolumn{9}{|c|}{$\begin{array}{l}\text { 3.1.1. Organo-chlorinated pesticides (ng. } \mathrm{g}^{-1} \text { dry weight) Limit of Quantification }=1 \\
\text { ng.g } \mathrm{g}^{-1} \text { d.w. }\end{array}$} \\
\hline $\mathrm{y}-\mathrm{HCH}$ (lindane) & $<1.0$ & 1.5 & 3.3 & 4.8 & $<1.0$ & 3.8 & 1.2 & 5 \\
\hline$p, p^{\prime}$ DDT & $<1.2$ & 4.6 & 3.1 & 3.3 & 2.1 & 1.3 & $<1$ & 3.2 \\
\hline$p, p$ ' DDE & 2.4 & 12.3 & 11.7 & 17.2 & 5.3 & 5.7 & 6 & 12.5 \\
\hline$p, p^{\prime} \mathrm{DDD}$ & $<1.0$ & 2.6 & 2.9 & 3.3 & 1.1 & 1.2 & 1.8 & 2.3 \\
\hline \multicolumn{9}{|c|}{7 ICES Marker PCBs (ng.g ${ }^{-1}$ dry weight) Limit of Quantification $=1 \mathrm{ng} \cdot \mathrm{g}^{-1}$ d.w. } \\
\hline PCB28 & $<1.0$ & 2.1 & 4.5 & 6.4 & $<1.0$ & 1.2 & 1.4 & 4.4 \\
\hline PCB52 & $<1.0$ & 11 & 15.2 & 22.6 & 2.6 & 4.7 & 3.3 & 7.6 \\
\hline PCB101 & 2.8 & 18.7 & 21.5 & 34.5 & 7.0 & 5.9 & 6.9 & 12.7 \\
\hline PCB118 & 2.4 & 11.4 & 15.3 & 21.3 & 4.9 & 5.6 & 6 & 10.2 \\
\hline PCB138 & 7.1 & 22.6 & 23.6 & 38.2 & 11.4 & 9.9 & 10.8 & 21.8 \\
\hline PCB153 & 13.9 & 41.1 & 37.7 & 58.0 & 21.9 & 17.7 & 19.3 & 36.8 \\
\hline PCB180 & 7.2 & 19 & 15.8 & 22.4 & 7.7 & 6.6 & 2.4 & 12.5 \\
\hline \multicolumn{9}{|c|}{ 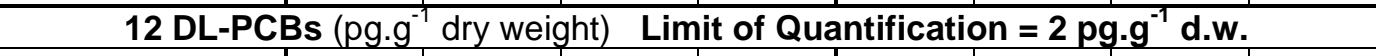 } \\
\hline 3.1.2. РCB77 & 12 & 82 & 103 & 113 & 23 & 35 & 40 & 93 \\
\hline PCB81 & $<2$ & 32 & 31 & 47 & 5 & 4.1 & $<2$ & 25.7 \\
\hline PCB126 & $<2$ & 102 & 66.4 & 115 & 11.3 & 16.9 & $<2$ & 118 \\
\hline PCB169 & 12 & 23 & 35 & 39 & 5.4 & $<2$ & $<2$ & 30.6 \\
\hline PCB105 & 664 & 4750 & 6365 & 10700 & 1940 & 2040 & 3100 & 5245 \\
\hline PCB114 & 38.6 & 394 & 445 & 542 & 105 & 138 & 160 & 347 \\
\hline PCB118 & 2190 & 20000 & 20500 & 31600 & 5140 & 6730 & 7900 & 15050 \\
\hline PCB123 & 124 & 754 & 926 & 689 & 397 & 392 & 483 & 708 \\
\hline PCB156 & 429 & 2560 & 2365 & 3780 & 885 & 800 & 1210 & 2105 \\
\hline PCB157 & 151 & 626 & 475 & 733 & 234 & 253 & 336 & 617 \\
\hline PCB167 & 350 & 1920 & 1445 & 2160 & 661 & 621 & 802 & 1555 \\
\hline
\end{tabular}




\begin{tabular}{|c|c|c|c|c|c|c|c|c|}
\hline PCB189 & 86 & 409 & 241 & 372 & 94 & 113 & 134 & 259 \\
\hline \multicolumn{9}{|c|}{2378 TCDD - Toxic Equivalent Quantity (pg.g ${ }^{-1}$ dry weight) } \\
\hline TEQ & $<0.7$ & 11.8 & 8.7 & 14.2 & $<1.6$ & $<2.1$ & $<0.7$ & 13.5 \\
\hline TEQ & $<0.9$ & 14.8 & 11.5 & 18.8 & $<2.6$ & $<3.2$ & $<2.2$ & 15.8 \\
\hline TEQ ${ }_{\mathrm{PCDD} / \mathrm{Fs}} 2006$ & $<0.9$ & $<1.0$ & $<1.1$ & $<1.4$ & $<1.6$ & $<1.2$ & $<1.8$ & $<2.4$ \\
\hline TEQ $_{\mathrm{PCDD} / \mathrm{Fs}} 1998$ & $<1.0$ & $<1.1$ & $<1.2$ & $<1.4$ & $<1.9$ & $<1.2$ & $<2.2$ & $<3.1$ \\
\hline TEQ $_{\text {Total }} 2006$ & $<1.6$ & $<12.8$ & $<9.9$ & $<15.6$ & $<3.5$ & $<3.3$ & $<2.9$ & $<16.6$ \\
\hline TEQ $_{\text {Total }} 1998$ & $<1.9$ & $<15.9$ & $<12.7$ & $<20.2$ & $<4.5$ & $<4.4$ & $<4.4$ & $<18.9$ \\
\hline \multicolumn{9}{|c|}{ 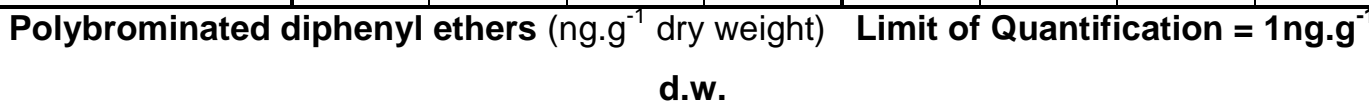 } \\
\hline 3.1.3. PBDE47 & $<1.0$ & 6.7 & 3.4 & 10.1 & $<1.0$ & 2.7 & $<1.0$ & 4.2 \\
\hline
\end{tabular}

\section{1. $\mathrm{HCH}$ and DDT groups}

Hexachlorocyclohexane has been formerly used an insecticidal mixture in which the $\alpha, \beta$, and $y$ isomers are the main components, with the $y$ isomer being the active one. The use of this technical mixture has been banned since 1988 in France. The use of lindane, the $\mathrm{y}$ isomer enriched formulation, has been restricted for about 20 years, and lindane has not been produced or used in France since 2008 (www.ineris.fr/substances). Neither in the shads nor in the grey mullets, $\alpha-\mathrm{HCH}$ was quantified $\left(\mathrm{LOQ}=1 \mathrm{ng} \cdot \mathrm{g}^{-1}\right)$, but $\beta-\mathrm{HCH}$ was found in four out of eight samples at concentrations between LOQ and $1.3 \mathrm{ng} \cdot \mathrm{g}^{-1} \mathrm{~d} . \mathrm{w}$. $\mathrm{y}^{-}$ $\mathrm{HCH}$ was measured in all samples at concentrations ranging from 1 to $5 \mathrm{ng} \cdot \mathrm{g}^{-1}$ d.w. Most of the higher levels were found in fish upstream of the dam in the freshwater part of the Vilaine River which might result from recent use of this pesticide.

The DDT group includes DDT itself and its two metabolites DDD and DDE, all of which have two isomers, the o, $p^{\prime}$ and $p, p^{\prime}$ forms. Among the six possible compounds, the $p, p^{\prime}$ isomers were more frequently measured in the fish. Despite its very restricted use, DDT is still found at very low levels in fish with concentrations varying between $<1$ and $4.6 \mathrm{ng} \cdot \mathrm{g}^{-1} \mathrm{~d} . \mathrm{w}$. DDD was found at concentrations between $<1$ and $3.3 \mathrm{ng} \cdot \mathrm{g}^{-1} \mathrm{~d} . \mathrm{w}$. DDE, the more persistent metabolite, was found in all samples at higher concentrations varying between 2.4 and $17.2 \mathrm{ng} . \mathrm{g}^{-1} \mathrm{~d} . \mathrm{w}$. The most contaminated fishes were taken upstream to the dam. Low DDT/DDE+DDD+DDT ratios, on average between 0.10 and 0.20 , confirm there was no recent DDT emission into the riverine environment.

\subsection{PBDEs}

Polybrominated diphenyl ether residues in fish result from their extensive use as flame retardants. Various technical formulations with different degrees of bromination were used and progressively regulated. Presently, the decabrominated mixture is the only polybrominated diphenyl still in used in Europe. PBDEs, less brominated compounds, are known to bioaccumulate in aquatic organisms. Concentrations in aquatic organisms were around a few ng.g 1 and PBDE47 (4 $\mathrm{Br}$ atoms/molecule) was the main compound measured in biological tissue despite the present use of more brominated mixtures. Several authors have retrospectively analyzed bank specimens showing either an increase or a possible decrease of the PBDE contamination since the 1980s 
(Sellstrom et al. 2003 ; Johansson et al. 2006). There is no toxicological reference value or environmental assessment criteria for PBDEs.

In the PBDE group, only PBDE47 was quantified in five among the eight analyzed samples; the concentrations vary from 1 to $10 \mathrm{ng} \cdot \mathrm{g}^{-1} \mathrm{~d}$.w. Compared with those of other man-made compounds, these levels are quite high. This may be because of the large measurements uncertainties due to very small sample amounts taken for the analysis. However, for both the allis shad and the grey mullet, the concentrations of PBDE47 was higher in fish collected in 2005 than in 2004, and for other contaminants, the concentrations were higher in upstream samples than in those taken downstream of the dam.

\subsection{Dioxins and PCBs}

Dioxins (PCDDs and PCDFs) were present at very low levels, around the limit of quantification for most of the 17 different compounds. The TEQs $\mathrm{PCDD} / \mathrm{Fs}_{\mathrm{s}}$ were always less than 3.1 pg.g ${ }^{-1}$ d.w. (TEQ PCDD/Fs $_{2} 2006<2.4$ pg.g ${ }^{-1}$ d.w.) which is much lower than the maximum concentrations in food according to European regulations; the maximum concentrations for dioxins $T E Q_{1998}$ was set at $4 \mathrm{pg} \cdot \mathrm{g}^{-1}$ w.w. (Anon., 2006) has been recently lowered to $T^{2} Q_{2006}=3.5 \mathrm{pg} . \mathrm{g}^{-1}$ w.w. (Anon., 2011) using the recently readjusted TEFs (Van den Berg et al., 2006). Most of the 2378-substituted components were not quantified (<LOQ: $0.5 \mathrm{pg} \cdot \mathrm{g}^{-1}$ d.w.). The main components found at higher levels were 2378-TCDF (0.5-8.6 pg.g ${ }^{-1}$ d.w.), OCDD (2-7.3 pg.g ${ }^{-1}$ d.w.), 1234678 - HpCDD (2-7.3 pg.g ${ }^{-1}$ d.w.), 23478 - PeCDF (0.6-3.8 pg.g ${ }^{-1}$ d.w.), 12378 - PeCDF (0.6-1.6 pg.g ${ }^{-1}$ d.w.). The highest concentrations were measured in fish samples collected upstream of the dam.

PCBs represent a large group of man-made chemicals which are typical persistent contaminants which bioaccumulate. They are found in the environment as a result of their previous use as insulator fluids in electric equipments. The production was phased out in 1987 in France but they are still found in the aquatic environment, particularly in urbanized and industrial areas. Among the large group of the PCB family two sub-groups were determined: the DL-PCBs, the 12 non ortho or mono-ortho chlorinated congeners which present the same toxicity mechanisms as PCDDs or PCDFs and which contribute largely to the Toxic Equivalent Quantity and the seven ICES-PCBs which are systematically found in all fishes samples (Table 2).

DL-PCBs were present at concentrations, between $<0.7$ and 18.8 pg.g ${ }^{-1}$ d.w. expressed in TEQs. There are no regulations on the maximum levels of DL-PCBs in food but only for the total TEQ (TEQ reasons as for $T E Q_{P C C D s / P C D F s}$, the maximum level for total TEQ has been recently lowered from 8 to $6.5 \mathrm{pg} . \mathrm{g}^{-1}$ wet weight (Anon., 2011) or approximately from 40 to $32 \mathrm{pg}^{-1}$ on a dry weight basis. These results show that the dioxins contamination in these fish samples is reasonably low on average, at about 5-15 $\%$ of the maximum residue limits (MRL). DL-PCB concentrations are much more variable. The contributions of DL-PCBs are surprisingly high; compared with the food safety limits the total TEQ is about $10-50 \%$ of the limit and DL-PCBs contribute for about 30 to $90 \%$ to the Total TEQ. On the basis of their actual measured concentrations, the composition of DL-PCBs is dominated by the congeners PCB118 (53-62\% of the sum of the DL-PCBs) followed by PCB105 (16-23\%), PCB156 (7-10\%), and PCB167 (4-8\%). The relative importance of the DL PCBS changes when their contribution to the TEQ is considered. The more toxic compounds, the main contributors to the TEQ, are by decreasing importance PCB126 (13-88\%), PCB118 (4-33\%), PCB156 (1-26\%), PCB169 (1- 
17\%), and PCB105 (1-11\%). These DL-PCBs congeners, more particularly the compounds PCB126 and 169, are among the least concentrated components in the studied fish samples, therefore the measured values have a larger variability. This uncertainty is thought to be the likely reason why the contribution of DLPCBs to the total TEQ is so high and so variable.

All samples of the seven ICES-PCBs presented very similar PCB patterns, which is commonly observed in fishes with an approximately constant composition in all the samples, and where PCB153 predominates over the other congeners (Figure 2). This component, 22 '44'55'- hexachlorinated biphenyl, has been recognized as one of the major compounds in the formerly used technical PCB mixtures, as well as one of the most recalcitrant to any degradation processes, due to the relative position of the chlorine atoms on the biphenyl structure.

Figure 2: PCB concentration patterns in the grey mullet and the allis shad caught in the Vilaine River, upstream and downstream of the Arzal dam in 2004 and 2005. (On each histogram, from left to right: PCB28, 52, 101, 118, 153, 138, 180)

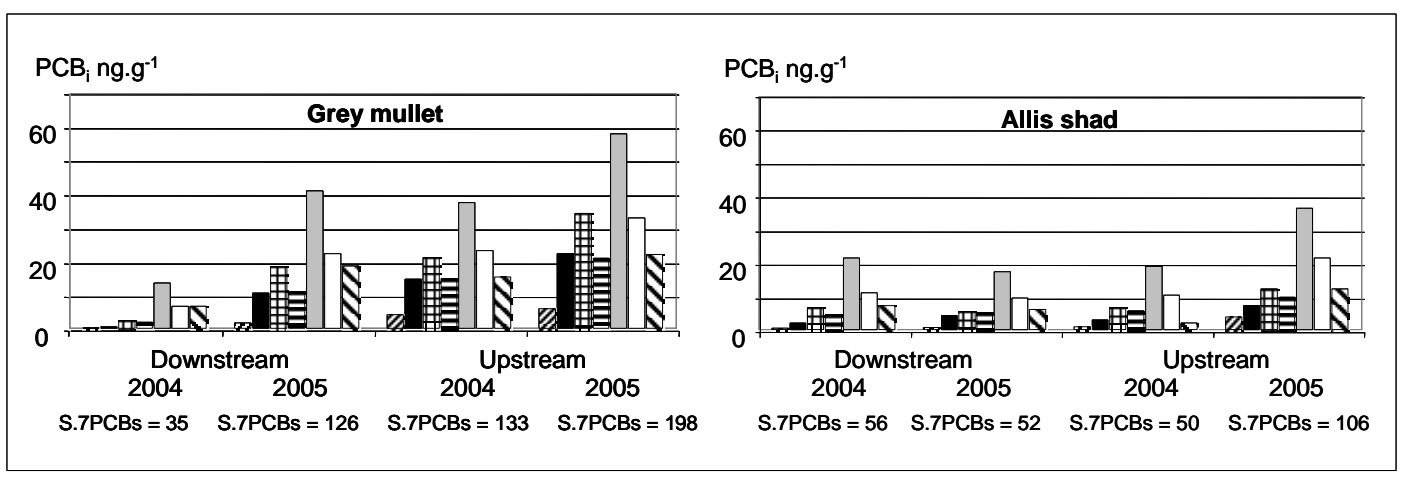

The sum of concentrations of the seven marker PCBs vary between 35.3 and $173.4 \mathrm{ng} . \mathrm{g}^{-1} \mathrm{~d}$.w. in the fish samples. The lowest and highest concentrations were measured in the grey mullet whereas the concentrations in the allis shad fell around 50-60 ng.g ${ }^{-1}$, except in the samples collected in 2005, upstream of the dam. The food safety limits for PCBs markers have been recently established for the sum of the six PCB congeners (Anon. 2011), the seven ICES PCBs minus PCB118, which is a DL-PCB. This maximum concentration has been set at 75 ng. $\mathrm{g}^{-1}$ wet weight in fish (Anon. 2011), or approximately 300-350 $\mathrm{ng} . \mathrm{g}^{-1} \mathrm{~d}$.w. The corresponding concentrations in the allis shad and the grey mullet samples were in the ranges 44-100 and 27-177 ng.g $^{-1}$ d.w., respectively, or around from one tenth to half the safety limits.

Too few samples were analyzed to allow a sound statistical evaluation of the data. However, on average the results show no differences between the average concentrations in the two species: mean PCB153 concentration in the grey mullet 33.7 ng.g ${ }^{-1}$ d.w. (C.I.: 15.3-51.9) and in the allis shad 25.7 ng.g ${ }^{-1}$ d.w (C.I.: 16.534.9). Obviously, according to the graphs (fig.2) it appears that samples collected in 2005 are more contaminated than those from 2004 except for the allis shad samples collected downstream. Last and more importantly, the samples from upstream of the dam are more contaminated than the downstream samples in the case of the grey mullet but to a lesser extent for that of the allis shad. This observation was common to most of the contaminants analyzed in the study. In the case of the grey mullet, its diet in the freshwater part is a likely explanation; mullet feed on material of detrital origin and partly on sediment. In the case of the allis shad the question of the dietary intake of contaminants remains open. 
Several authors have confirmed that shads stop feeding when they reach freshwater for spawning. According to Taverny (personal communication), none of the shads collected in the freshwater course during their migration has been observed to have feed immediately before they were caught and examined. Therefore, although feeding is the main way that contributes to bioaccumulation, it is surprising to measure higher concentrations in shads from upstream areas where they supposed not to eat during the spawning period. Loss of weight during fasting period and consequently remobilization of fats and redistribution of fats within the whole body of fishes might modify the contamination levels in fatty tissues which could either produce an increase of contaminant as often observed or a decrease. These effects might be difficult to observe in such a limited set of samples in muscle tissues which are not considered as fatty tissues and in a clean aquatic environment. Some other confusing factor could also act on the distribution of lipids and of contaminants and particularly the effect of reproduction as well as a possible balance of contaminants in fish by intake of contaminated preys. At last few very thin specimen of shad were caught in the upstream part that obviously have already spawned and showed a loss of muscle mass. Consequently, at this stage, there is no clear explanation for these higher contamination levels. In 2005, the sum of seven PCB concentrations in fish from the river was approximately twice as high as in those from the euryhaline area at the same sampling period. Possible contamination of the upstream part of the river was investigated. Data obtained in 2010 during a monitoring programme (Plan National PCB - Ministère de l'Environnement http://www.pollutions.eaufrance.fr/pcb/resultats-xls.html) confirmed that a contamination gradient of the sediment along the river course with the sum of seven PCBs around $27 \mu \mathrm{g} \mathrm{kg}^{-1}$ (dry weight) at Langon, far upstream of the Arzal dam and only $14 \mu \mathrm{g} \mathrm{kg}^{-1}$ downstream. Such observation is usual in tidal estuaries were sediment from the upper part is mixed with less contaminated sandy coarse particles of marine origin.

Pastel et al. (1980) made similar observations on 52 male American shad (Alosa sapidissima) collected during the spring of 1977 at two sites in the lower part of the Hudson River (N.Y.), located 27 and 75 miles from the river mouth. This river was exposed to high PCB pollution between 1950-1975. Fish collected from the downstream site contained a mean PCB concentration of $2000 \pm 1000 \mathrm{ng} \mathrm{g}^{-1}$, wet weight; fish from the upstream site contained a mean PCB concentration of 6100 $\pm 2700 \mathrm{ng} \mathrm{g}^{-1}$.w.w. These concentrations, approximately 10,000 (upstream) to 30,000 ng. $\mathrm{g}^{-1}$ (downstream) on a dry weight basis cannot directly be compared with the results of this present study, which is two orders of magnitude less contaminated because of the change in the determination and expression of PCB concentrations from technical mixture equivalent to individual congener. However, the main finding is the observation of higher concentrations in fish collected upstream despite the fact that shads do not eat in fresh water before spawning. Pastel et al. (1980) have suggested that the bioaccumulation of PCBs in shads occurred mainly by dietary intake in the marine environment. This observation raises the question of the main source of exposure to PCBs. According to Van Geest et al (2011), beside dietary intake, fish are contaminated by PCBs either directly, by contact with the contaminated superficial sediment, or from water through the gills during respiration, in the case of the more soluble PCB components. The direct bioaccumulation from the water represents a very minor part of the PCB body burden in fish and is limited to the more soluble and less chlorinated components.

Information on the contamination of the anadromous species is scarce. Lochet et al. (2008) has studied the mercury contamination of shads, allis shad and twaite shad (Alosa fallax) in the Gironde estuary. They have observed that mercury 
contamination of adult shads results from their dietary intake during their marine stage by feeding. Schnitzler et al. (2011) have published on the contamination by organochlorinated in another euryhaline species, the sea bass (Dicentrarchus labrax), from several large estuaries in France. As expected, higher contamination was found in fish from the Seine $\left(46,4 \pm 21,6 \mathrm{ng} \cdot \mathrm{g}^{-1}\right.$ w.w.), and slightly lower contamination was found in those from the Gironde $(26,8 \pm 13,1 \mathrm{ng}$ $\mathrm{g}^{-1}$ w.w.) and the Loire $\left(14,6 \pm 8,7 \mu \mathrm{g} \mathrm{kg}{ }^{-1}\right.$ w.w.). According to the screening study CALIPSO (Leblanc, 2006), average levels of marker PCBs are about $38 \mathrm{ng}$ $\mathrm{g}^{-1}$ w.w. in the sea bass from four different various areas along the French coast. The contamination levels measured reported in the present study on diadromous fish from the Vilaine River are more or less in agreement with these figures.

The grey mullet leaves the river in autumn to reproduce in winter in the marine coastal spawning areas. Conversely, it migrates towards fresh water at spring and early summer. During the reproduction period the grey mullet stops feeding. In brackish water the grey mullet is both a detritus feeder and an omnivore. This mixed trophic status makes it easy to ingest large amounts of mud and sandy sediment, of mean grain size varying from 5 to $50 \mu \mathrm{m}$ (Bruslé, 1981. Sauriau, 1994. Alemeida, 2003). In their study on the PCB contamination of fish in the Rhône River around Lyon, Babut and Miège (2007) have observed much higher PCB concentrations in the common bream (Abramis brama) 650 ng.g ${ }^{-1}$ w.w. collected at Vernaison (south of Lyon) than in predator species like the pike (Esox lucius) and the pikeperch (Sander lucioprecia) contaminated at levels around 31,2 ng. ${ }^{-1}$ w.w.. Like the bream, the grey mullet feeds on muddy sediment and both these species likely are contaminated by eating sediment particles and small benthic species. The same question has arisen during a study in Narragansett Bay (New Brunswick, Canada) where Morgan and Lohmann (2010) observed that most of the fish that exceeded the food safety limit were migratory species and that PCB bioaccumulation was more important in benthic species compared with pelagic ones.

The effect of age on bioaccumulation has not yet been discussed so far in the present study. All the analyzed fish samples are constituted of adult specimens of the same year class, $7 / 8$ years old for the grey mullets and 5 years old for the allis shads except in the case of the batch made of younger shads in their $2^{\text {nd }}-3^{\text {rd }}$ year collected in spring 2004 downstream of the dam. The PCB concentrations depends directly on the exposure and that is likely to hold true for the other POPs. The effect of age might act on contamination: the measurement of lower concentrations in the grey mullets (5 years old and not 7/8 y.) apparently confirms contamination levels - time exposure relations. Analyses in older fishes, from the same class year as in the other groupings would have as expected confirm this assumption. Regarding the allis shad, approximately the same contamination levels are measured either downstream or upstream fishes, despite the fact that younger fishes were obtained in 2004. At this stage, the young fish remain within the estuary passing several successive times from one side of the dam inversely and their diet is mainly made of small crustaceans (copepods and mysids) (Bracken and Kennedy, 1967). During this period, contamination may occur only in the estuarine zone and shads consume their lipid reserves previously made during the marine stage for spawning. Therefore, this will result in weight loss of up to half their body weight (Mennesson-Boisneau et al., 2000b). Organochlorinated and, other hydrophobic contaminants, are accumulated in lipid rich tissue, and therefore, the weight loss should increase contamination. However, this decrease was not observed, particularly in 2005. The gender is an other factor acting on the contamination levels as lipids are mobilized for the maturations of gonads in female adult dab fishes at spring (Loizeau and Abarnou, 1994). In this study much higher and variable 
contamination levels were measured in gonad of female at spring than in those of males whereas no significant differences are observed in muscle tissue from those same fishes. It means that in our present study the results of the analysis of muscle tissue in pooled samples should not be affected by an effect of the gender and /or the non-parity in pooled samples.

This study has shown that fish from the Vilaine River have low amount of contamination, which hopefully indicates a safe situation in the river basin. Except accidental and localized pollution by PCBs, the Vilaine River has remained sheltered from high environmental contamination by PCBs and other man-made chemicals. This is more or less the situation in this western part of France, demonstrated through by occupational exposure monitoring; the comparison of data on human blood contamination obtained in different areas in France (Bachelet et al, 2011) show higher levels in the Eastern part. However, such surveys are beyond the objectives and means of our study.

Our results on the contamination of shads and grey mullet have showed a moderate contamination of the fish. The dietary intake of contaminants by diadromous species and their modification during migration for spawning remains still insufficiently explained. PCBs have shown to be potentially good markers for tracing back the underlying processes of bioaccumulation in the case of diadromous species; if other bioaccumulative compounds which are commonly found in only one side of the estuary, riverine vs marine part their analysis could bring useful information on that point. They may be used in future study because they can help to differentiate food sources of either marine or riverine origin, or those of the foodwebs of diadromous species at different stages in their life cycle. If further similar investigations are planned, they should aim to differentiate the seasonal and local effect during two or more consecutive years with a special care on the sampling strategy, particularly the number of fish samples to be analyzed and an optimized analytical protocols samples in term of sensitivity. Future research should also emphasis on the origin of PCBs in this part of the French shore. Because the susceptibility of PCBs to degradation and biomagnification is dependant on the PCB congener, the composition of PCB weathered mixtures differs from that of the original industrial mixtures released directly into the environment. Atmospheric transport is the most important mechanism for global dispersion of PCBs thus the dominant source of PCBs to surface waters is atmospheric deposition, but because there are no clear close sources of PCBs in the Vilaine river it would be interesting to determine whether migratory species contaminated through the marine food web or through contaminated sediment in the estuary.

\section{References}

Almeida PR, Moreira F, Costa JL, Assis CA, Costa MJ (1993) The feeding strategy of Liza ramada (Risso, 1826) in fresh and brackish water in the river Tagus, Portugal. J Fish Biol 42: 95-107

Almeida PR (2003) Feeding ecology of Liza ramada (Risso, 1810) in a southwestern estuary of Portugal. Estuar Coast and Shelf Sci 57: 313-323

Anon. (2006) Commission regulation (E.C.) No 1881/2006 of 19 December 2006 setting maximum levels for certain contaminants in foodstuffs. Offic $\mathrm{J}$ Eur Union 20.12.2006 L 364/5

Anon. (2011) Commission regulation (E.C.) No 1259/2011 of 2 December 2011 amending Regulation (EC) No 1881/2006 as regards maximum levels for dioxins, 
dioxin-like PCBs and non dioxin-like PCBs in foodstuffs. Offic $\mathrm{J}$ Eur Union 3.12.2011 L 320/18

Bachelet D, Truong T, Verner MA, Arveux P, Kerbrat P, Charlier C, GuihenneucJouyaux C, Guénel P (2011) Determinants of serum concentrations of 1,1dichloro-2,2-bis (p-chlorophenyl) ethylene and polychlorinated biphenyls among French women in the CECILE study. Environ Res 111: 861-870

Babut M, Miège C (2007) Contamination of fish and sediments by PCBs in the Rhone river (France). Data collected in 2005-2006. In: Cémagref/Préfecture du Rhône report. Dir Citoyen Environ 36p (in French)

Baglinière JL (2000) The genus Alosa. In: Baglinière JL., Elie $P$, ed. The shads (Alosa alosa and Alosa fallax spp.): Ecobiology and Diversity of Populations, Paris Inra-Cémagref: p. 3-30 (in French)

Baglinière JL, Sabatié MR, Aprahamian MW, Alexandrino $\mathrm{P}$, Aprahamian CD, Assis CA, Cassou-Leins JJ, Le Corre M, Mennesson-Boisneau C, MartinVandembulcke D, Rochard E, Teixeira C (2001) Guide for interpretation of scales and assessment of age in the shads (Alosa alosa) from the French East-Atlantic shore and French West-Mediterranean sea. Bull Fr Pêche Piscic 357-360:485531. (in French)

Baglinière JL, Sabatié MR, Rochard $E$, Alexandrino $P$, Aprahamian MW (2003).The Allis Shad Alosa alosa: Biology, Ecology, Range and Status of Populations. In: "Biodiversity, Status, and Conservation of the World's Shads" Limburg KE, Waldman JR (Ed). Am Fish Soc.Sym. Bethesda, Maryland, USA, 85-102

Birnbaum L.S., Staskal-Wikoff D.S. (2010) 5th international PCB workshop Summary and implications. Environment International 36 814-818

Bracken J, Kennedy M (1967) Notes on some Irish estuarine and inshores fishes. Irish Fisheries Investigations, Series B (Marine), N³, 28 pp

Bruslé J (1981) Food and feeding in grey mullets. In: Aquaculture of grey mullets, Oren E H Ed. Cambridge Univers Press, Cambridge, Massachusetts 185-217

Johansson II, Héas-Moisan K, Guiot N, Truquet I, Munschy C, Tronczyński J (2006) Polybrominated diphenyl ethers (PBDEs) in mussels from selected French coastal sites: 1981-2003. Chemosphere 64(2): 296-305

King JJ, Roche WK (2008) Fish and diadromy in Europe. Aspects of anadromous allis shad (Alos alosa) and twaite shad (Alosa fallax) biology in four Irish Special Areas of Conservation (SACs): status, spawning indications and implication for conservation designation. Hydrobiologia 602:145-154

Law R, Allchin J, Colin R, de Boer J, Covaci A, Herzke D, Lepom P; Morris S, Tronczynski J, de Wit, CA (2005) Levels and trends of brominated flame retardants in the European environment. Chemosphere, 64(2): 187-208

Leblanc JC, coord. (2006) CALIPSO fish and seafood consumption study and biomarker of exposure to trace elements, pollutants and omega3. Afssa/Dgal/Inra. 160p.

Lochet A, Maury-Brachet R, Poirier C (2008). Mercury contamination and life history traits of Allis shad Alosa alosa (Linnaeus, 1758) and Twaite shad Alosa fallax (Lacépède, 1803) in the Gironde estuary (South West France). Hydrobiol 602: 99-109

Loizeau L, Abarnou A (1994). Distribution of polychlorinated biphenyls in dab (Limanda limanda) from the Baie de Seine. Mar Environ Res, 38: 77-91 
Mennesson-Boisneau C, Aprahamian MW, Sabatié MR, Cassou-Leins JJ (2000a) Adult characterization. In: Baglinière JL., Elie $\mathrm{P}$, ed. The shads (Alosa alosa and Alosa fallax spp.): Ecobiology and Diversity of Populations, Ecobiology and Diversity of Populations. Paris Inra-Cémagref; p. 33-54 (in French)

Mennesson-Boisneau C, Aprahamian MW Sabatié MR Cassou-Leins J-J (2000b) Upstream Migration of adults. In: Baglinière JL., Elie P, ed. The shads (Alosa alosa and Alosa fallax spp.): Ecobiology and Diversity of Populations, Paris InraCémagref, pp. 55-72 (in French)

Morgan EJ, Lohman R (2010) Dietary uptake from historically contaminated sediments as a source of PCBs to migratory fish and invertebrates in an urban estuary. Environ Sci Technol 44: 5444-5449

Pastel M, Bush B, Kim JS (1980) Accumulation of Polychlorinated Biphenyls in American shad during their migration in the Hudson River, spring 1977. Pestic Monit J 14(1): 11-22

Sabatié MR (1993) Research on biology and ecology of shads (Alosa alosa and Alosa fallax) in Morocco. Dissertation, University of Bretagne Occidentale, France (in French)

Sauriau PG, Marchand J Goinard N (1994) Summer mortality of the grey mullet Liza ramada in the Loire estuary: Synthetic report. In: Asso. Protect. Environ. Loire Estuary. 1984-1994 47-59 (in French).

Schnitzler JG, Thomé JP, Lepage M, Das K (2011) Organochlorine pesticides, polychlorinated biphenyls and trace elements in wild European sea bass (Dicentrarchus labrax) of European estuaries. Sci Total Environ 409: 3680-3686

Sellstrom U, Bignert A, Kierkegaard A, Haggberg L, de Wit CA, Olsson M, Jansson B, (2003) Temporal trend studies on tetra- and pentabrominated diphenyl ethers and hexabromo-cyclododecane in guillemot egg from the Baltic Sea. Environ Sci Technol 37(24): 5496-5501

Taverny C (1991) Contribution to the knowledge of the population dynamics of shads in the estuarine waters of the Gironde river (France), Dissertation, University of Bordeaux I, France (in French).

Van den Berg M, Birnbaum L, Bosveld AT et al. (1998) Toxic equivalency factors (TEFs) for PCBs, PCDDs, PCDFs for humans and wildlife. Environ. Health Perspect 106: 775-792

Van den Berg M, Birnbaum LS, Denison M et al (2006) The 2005 World Health Organization reevaluation of human and mammalian Toxic Equivalency Factors for dioxins and Dioxin-Like Compounds, Toxic Sci 93(2): 223-241

Van Geest JL, Mackay D, Poirier DG (2011) Accumulation and depuration of polychlorinated biphenyls from field-collected sediment in three freshwater organisms. Environ Sci Technol 45: 7011-7018.

Yogui GT, Sericano JL (2009) Polybrominated diphenyl ether flame retardants in the U.S. marine environment. A review. Environment International 35: 655-666 